\title{
Effect of Different Technological Factors on the Gelation of a Low-Lectin Bean Protein Isolate
}

\author{
Helena M. Moreno ${ }^{1}$ (D) M. Teresa Díaz ${ }^{2} \cdot$ A. Javier Borderías ${ }^{3} \cdot$ Fátima Domínguez-Timón $^{3} \cdot$ Alejandro Varela $^{2}$. \\ Clara A. Tovar ${ }^{4} \cdot$ Mercedes M. Pedrosa²
}

Accepted: 15 February 2022 / Published online: 5 March 2022

(c) The Author(s) 2022

\begin{abstract}
Gelling ability of a bean protein isolate (BPI) obtained from a naturally low-lectin variety (Phaseolus vulgaris var. Almonga) was analysed. For that purpose differences on gels processing: concentration (14\% and 17\%), salt addition (0 and 2\%), and $\mathrm{pH}$ (6.5 -lot A- and 7 -lot B), were studied to obtain suitable colour, mechanical and viscoelastic properties for making appropriate meat and seafood analogues. Gelation at $\mathrm{pH} 7$ at both 14 and 17\% BPI concentrations, produced less rigid, more flexible, time-stable and cohesive gel networks. Colour of the resulting gels was white enough to be considered as an adequate base for making plant-based analogues. The content of total galactoside, inositol phosphates and trypsin inhibitors (bioactive compounds) present in one serving ( $100 \mathrm{~g}$ ) of these BPI gels were up to $0.80 \mathrm{mg} / \mathrm{g}, 8.06 \mathrm{mg} / \mathrm{g}$ and $239 \mathrm{TIUs}$, respectively.
\end{abstract}

Keywords Legumes $\cdot$ White bean protein isolate $\cdot$ Gelation $\cdot$ Mechanical properties $\cdot$ Viscoelasticity

\section{Introduction}

The use of plant protein isolates, particularly pulses, is of growing industrial interest due to their functional and technological properties but also their nutraceutical/health beneficial properties [1]. Different scientific studies have associated the consumption of legumes with physiological and health benefits, such as prevention of some types of cancer, cardiovascular diseases, type 2 diabetes, obesity, improvement of the metabolic syndrome, osteoporosis or chronic degenerative diseases $[2,3]$. These healthy roles have been linked with pulse proteins and some phytochemicals or

Helena M. Moreno

helena.moreno@ucm.es

1 Veterinary Faculty, Department of Food Technology, Avda. Puerta de Hierro, s/n, 28040 Madrid, Spain

2 Food Technology Department, National Agricultural and Food Research and Technology Institute (INIA), Ctra de La Coruña Km 7.5, 28040 Madrid, Spain

3 Products Department, Institute of Food Science Technology and Nutrition (ICTAN-CSIC), C/ José Antonio Nováis, 10, 28040 Madrid, Spain

4 Department of Applied Physics, Faculty of Sciences, University of Vigo, As Lagoas, 32004 Ourense, Spain bioactive compounds such as galactosides, phytates or phenolic compounds [4].

With the growth of vegetarianism and the demand for non-soy and non-wheat proteins in developed countries, dry beans (Phaseolus vulgaris L.) are receiving little by little increased attention for novel food formulations [5]. Although they have similarities, each variety of beans present a unique phytochemical profile [6, 7]. It is important to note that among these phytochemical, the $P$. vulgaris lectin (PHA) is considered as an antinutrient compound since it can be toxic for humans producing vomits, diarrhoea, bloating and interfering with nutrient absorption; however, some potential health benefits (anti-cancer, anti-microbial or reduction diabetes type 2) have been described [2, 6-8] PHA is a glycoprotein highly resistant to thermal denaturation in comparison to other plant proteins, and the presence of this lectin may be the reason for the underutilization of beans as ingredients, mainly, in the elaboration of those food products that are processed at low temperature and/or during a short time. Considering that it is not known the toxicity of all $P$. vulgaris beans they should be considered carefully the lectin intake [8]; therefore, the use of varieties with naturally lowlectin content could be an interesting option for the production of bean protein isolates and for the development of new safe and healthier food products $[4,7,8]$. This is the case of the commercially available common bean var. Almonga 
used in this study; a white dry bean in the planchada market class, with good culinary quality, and whose consumption has been reported to produce a significant reduction of triglyceride levels [6].

Protein isolates usually are obtained from bean flour by alkaline extraction followed by isoelectric precipitation [4]. Legume proteins comprise water-soluble albumins, globulins (legumins and vicilins) soluble in salt solutions, the family of lectin-related proteins, and a minor proportion of prolamins and glutelins soluble in dilute acid/base solutions. Thus, the final composition of the BPI plays an important role on the techno-functional properties, which are of great importance for gelation ability [9]. Moreover, there are some factors such as $\mathrm{pH}$, ionic strength and protein concentration that also affect gel formation [10]. Taking that into account, mechanical properties are important for the behaviour of food materials, and especially of gels, which are major features in consumer perception and acceptance [11]. These factors will result in gels with different characteristics such as texture, viscoelasticity, colour and flavour as the basis for processing final products that mimic seafood or meat products [12].

One important parameter to take under consideration during BPI gelation is the effect of $\mathrm{pH}$ on proteins and their influence on techno-functional properties. It has suggested that $\beta$-sheet can be reduced by acidic $\mathrm{pH}$, thus reducing the stability of the network structure. Also, $\mathrm{NaCl}$ may increase the presence of disordered structures such as random coil by reducing $\beta$-sheet [1], thus altering the physicochemical properties of the resulting gel.

The aim of this paper was to throw light on the gelation ability of a bean protein isolate from a variety with a lowlectin content ( $P$. vulgaris var. Almonga). The effects of BPI concentration, presence of salt, and $\mathrm{pH}$ were studied with a view to developing gels with suitable textures for making meat and seafood plant-based analogues, as well as with a bioactive compounds content sufficient to exert an effective health protective effect. To our knowledge this is the first research work done on the gelation ability of this low-lectin bean variety based on the electrophoretic analysis, mechanical and viscoelastic properties.

\section{Materials and Methods}

The methods used to determine the proximate composition of the bean protein isolate and their techno-functional properties ( $\mathrm{pH}$ and last gelation capacity), as well as the mechanical properties (puncture test), the electrophoretic profile, colour, viscoelasticity (oscillatory tests) of the gels and their bioactive compounds content are described in the supplementary material and methods file (Electronic supplementary material-1).

\section{Preparation of Bean Protein Isolates (BPI)}

Beans (P. vulgaris var. Almonga -Benjamín Rodríguez Álvarez, León, Spain-) was used to prepare the bean protein isolate by alkaline extraction followed by isoelectric precipitation (bean composition and additional details are given in Electronic supplementary material -1).

\section{Preparation of Bean Protein Isolate Gels}

Samples were prepared using the obtained BPI at three concentrations (14, 17 and 20\%). The lowest BPI concentration corresponds to the LGC value determined previously (Online resource 1) and that secure a suitable gel for the purpose of this work. The addition of $2 \%$ of $\mathrm{NaCl}$ and the $\mathrm{pH}$ adjustment of the gels resulted into the different sample codes: G14-A, G17-A and G-20-A with a final of pH 6.5 and G14-B, G17-B, G20-B with a final of $\mathrm{pH} 7.0$ for $0 \% \mathrm{NaCl}$, and 2G14-A, 2G17-A, 2G20-A, 2G14-B, $2 \mathrm{G} 17-\mathrm{B}, 2 \mathrm{G} 20-\mathrm{B}$ for the samples containing $2 \% \mathrm{NaCl}$ (additional details are given in Electronic supplementary material -1).

\section{Puncture Test}

It was firstly performed on all the gels prepared in order to select those with the most suitable mechanical properties (Online resource 1). The selected samples were included in the subsequent analyses and the others were discarded.

\section{Dynamic Rheometry (Stress Sweep Tests and Mechanical Spectra) of Bean Protein Isolate Gels}

Small amplitude oscillatory shear (SAOS) tests were performed for Lots A and B of BPI gels with the better mechanical properties from puncture tests (14 and 17\% BPI concentration and $0 \% \mathrm{NaCl}$ ) (additional details are given in Electronic supplementary material -1).

\section{Statistical Analysis}

One-factor ANOVA analysis was carried out with the SPSS ${ }^{\circledR}$ computer programme (SPSS Inc., Chicago, IL, USA) and average differences were evaluated by the Tukey test using a $95 \%$ confidence interval. Viscoelastic data were tested with expanded uncertainty limits as the maximum and minimum deviation from the respective mean 
values. Trends were considered significant when means of compared sets differed by $p<0.05$ (Student's test).

\section{Results and Discussion}

\section{Proximate Composition and Techno-Functional Properties of Bean Protein Isolate}

The chemical composition can influence the techno-functional properties of the isolate; in particular thermally induced gelation behaviour [9]. BPI moisture and ash content was $1.08 \% \pm 0.01$ and $4.70 \pm 0.06$, respectively. The content of total protein $(75.42 \% \pm 0.91$ d.w.) and fat $(3.86 \% \pm 0.20$ d.w.) of the BPI was in the range $70-77 \%$ and $2.5-4 \%$, respectively, reported in the literature, and the proportion of carbohydrates was $16.03 \% \pm 0.77$ (d.w.), of which $0.73 \% \pm 0.07$ (d.w) was starch and $3.27 \% \pm 0.07$ (d.w.) was dietary fibre. This proximate composition was similar to that reported by other authors for different varieties of kidney bean protein isolates [13]. The high proportion of soluble protein $(44.1 \% \pm 1.5$ d.w.) present in the BPI indicated that this isolate is suitable for use as an ingredient in different food applications. Vicilins and legumins (the main storage legume proteins) can form thermally-induced gels, although their gelation behaviour is slightly different and changes in the vicilin/legumin can affect the functionality of the protein isolate [14]. The legumin/vicilin ratio was 15.25 , indicating that this BPI is a legumin-rich isolate. The $\mathrm{pH}$ of the BPI powder in water dispersion was $5.33 \pm 0.02$. The legume protein isolates exhibit better techno-functional properties (such as gelation, foaming or emulsifying properties) at $\mathrm{pH}$ values close to neutral [15], for that reason the $\mathrm{pH}$ of the samples was raised up to 6.5 (lot A) and 7.0 (lot B). LGC was $14 \%$ BPI at natural $\mathrm{pH}$ (5.33), so, 14, 17 and $20 \%$ BPI gels were checked at both pHs to determine their mechanical characteristics according to the aim of this work. This LGC value of BPI was similar to that reported by some authors for red kidney bean faba bean or chickpea isolates $[12,15-17]$, and lower than that reported for pea or soybean isolates, these differences can be related to the influence of the type and variety of pulse studied [13].

\section{Mechanical Properties: Puncture Test on Bean Protein Isolate Gels}

The effect of salt $(0$ and $2 \% \mathrm{NaCl}$ ) on the mechanical properties of the gels were tested through a puncture test. The addition of $2 \%$ salt dramatically decreased the breaking force (BF) and breaking deformation (BD) for 2G14-A, 2G14-B, 2G17-A, 2G17-B, 2G20-A, 2G20-B vs G14-A, G14-B, G17A, G17-B, G20-A, G20-B (Fig. 1a and b). This is probably due to the presence of saline ions that alter the electrostatic balance of the charges that stabilized the BPI gel network without salt. This result indicates that higher ionic strength at $\mathrm{pH}$ higher than that of the isoelectric point increased the repulsive electrostatic forces among proteins weakening the inter-protein packing and consequently the mechanical resistance to gel rupture was reduced. The effect of $\mathrm{NaCl}$ concentration has also been related to the protein content in the medium, so the higher the ionic strength, the higher is the protein concentration required to form a proper gel network $[18,19]$. This is consistent with the results shown since the increase in BF and BD associated to the greater BPI concentration, was mitigated in presence of salt. Besides that, all gels made with $2 \%$ of $\mathrm{NaCl}$ (2G14-A, 2G14-B, 2G17-A, 2G17-B, 2G20-A, 2G20-B) had poor mechanical properties to be considered as proper gels to the aim of this study and were discarded for further analysis.

Focusing on the $\mathrm{pH}$ of gels, the narrow difference between them (6.5 vs 7.0) had a considerable impact on the gel properties, as evidenced by the higher values of $\mathrm{BF}(p<0.05)$ in

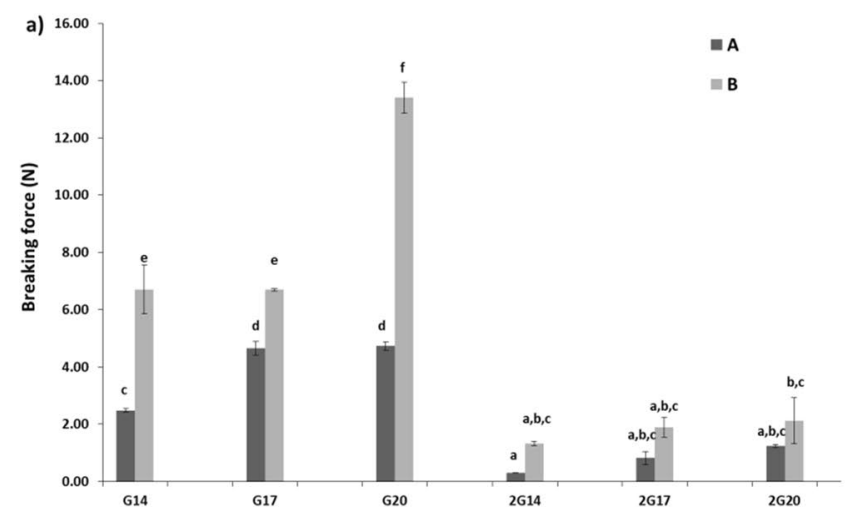

Fig. 1 Breaking force (a) and breaking deformation (b) for bean protein isolate (BPI) gels at different pHs. Different capital letters for each value indicate significant differences $p<0.05$ among samples

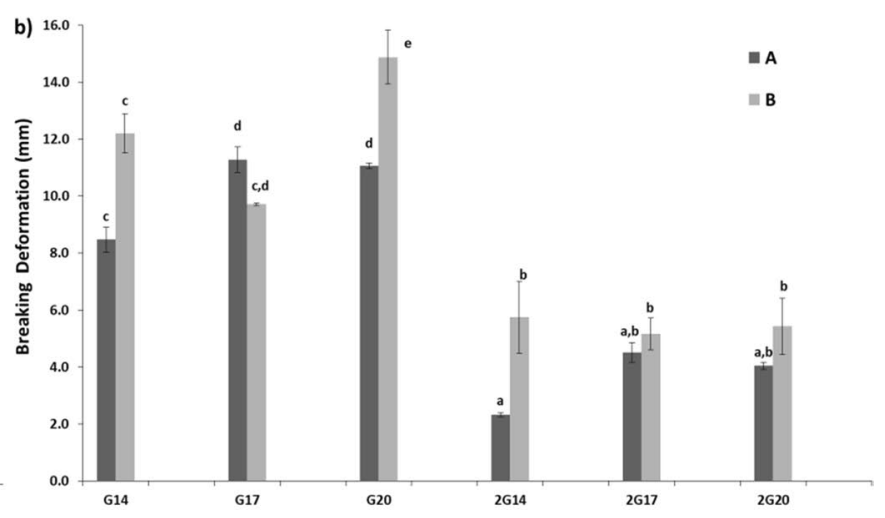

of $\mathrm{pH}=6.5$ (A -dark grey-) and $\mathrm{pH}=7$ (B -light grey-) without salt. Different lowercase letters for each value indicate significant differences $p<0.05$ among samples of $\mathrm{pH} \mathrm{A}$ and $\mathrm{B}$ with $2 \% \mathrm{NaCl}$ 
gels B ( $\mathrm{pH}$ 7.0) vs A ( $\mathrm{pH}$ 6.5), irrespective of BPI concentration (Fig. 1a). This could be related to the prevalent surface charge of the proteins at each $\mathrm{pH}$ [19]. Protein unfolding and aggregation is required to form an adequate gel, and it has been reported that legume protein isolates exhibit better functional properties at $\mathrm{pH}$ values close to neutral $[14,15]$. Gels containing 20\% BPI without salt (G20-B) were also rejected for the purpose of the study due to the extremely high values of BF and BD which are far from those desired to make meat and seafood products analogues.

\section{Electrophoretic Profile}

Bean proteins are composed mainly of vicilin (7S) and legumin (11S) and in the BPI of this low-lectin variety, vicilins made up $51.47 \pm 0.98 \%$ of the total proteins and legumins $72.1 \pm 1.0 \%$. Vicilin is a kind of glycoprotein frequently non-covalently associated in trimers (7-8S globulins) with a molecular weight of $150-250 \mathrm{kDa}$, or even hexamers, while the legumin consists of acidic (about $40 \mathrm{kDa}$ ) and basic (20 kDa) subunits linked by disulphide bonds [20].

The electrophoretic profiles of the above selected gels according to their mechanical properties (G14-A, G14-B, G17-A and G17-B) were similar, with bands corresponding to a molecular weight around 250 and $160 \mathrm{kDa}$ (vicilins) and 75, 40, 25 and $15 \mathrm{kDa}$ (Fig. 2), which are assumed to be legumin subunits [21]. As reported earlier, this low-lectin BPI is legumin-rich, which would explain the lower intensity of the vicilin bands as compared to legumins, particularly in the samples with 17\% BPI (Lot A and B).
Fig. 2 Electrophoretic profile for bean protein isolate (BPI) gels at different $\mathrm{pHs}$

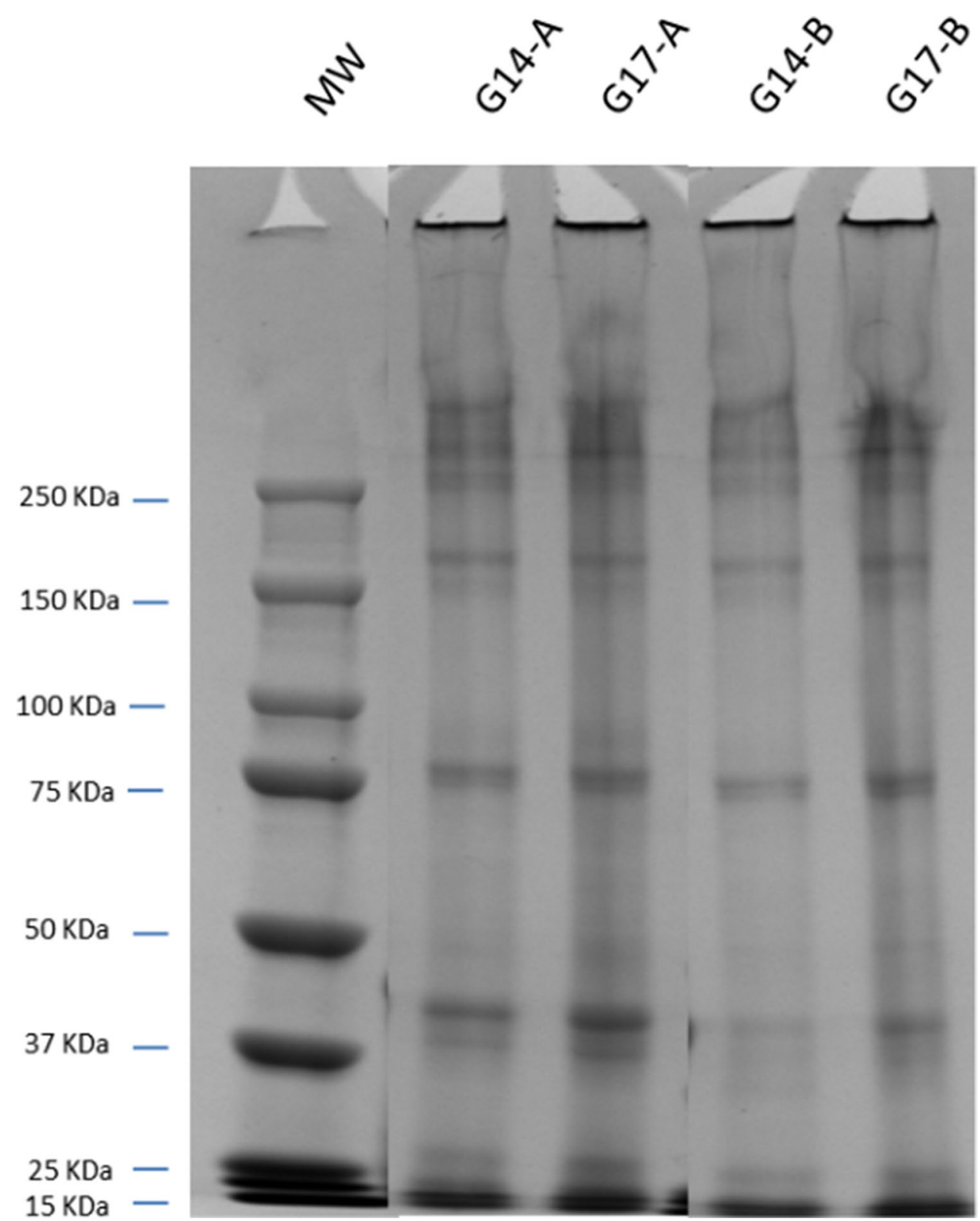


The presence of noticeable aggregates retained in the stacking electrophoresis gel [22] seems to be due to MTGase activity, which has the ability to form intermolecular aggregates [23] and in the formation of dimers and polymers of $11 \mathrm{~S}$ and $7 \mathrm{~S}[22,23]$.

Comparison of the A and B groups of gels showed that the bands most affected, regardless of BPI concentration, are the ones of the lowest molecular weight ( $40 \mathrm{kDa}$ and below), whose intensity is lower in $\mathrm{B}$ gels. The reason for the reduction in intensity of these bands (G14-B and G17-B) could be that the location of the reactive residues to MTGase in these proteins is more accessible [24].

\section{Colour of Bean Protein Isolate Gels}

Colour parameters $\left(\mathrm{L}^{*}, \mathrm{a}^{*}\right.$ and $\left.\mathrm{b}^{*}\right)$ and whiteness index (WI) of BPI gels are presented in Table 1. $\mathrm{L}^{*}$ varied between $73.55 \pm 0.15$ and $75.78 \pm 0.47$, indicating high luminosity; $\mathrm{a}^{*}$ ranged from $0.83 \pm 0.21$ to $0.04 \pm 0.03$, meaning no tendency to redness; while all the gels showed a positive $b^{*}$ ranging from $12.95 \pm 1.03$ to $15.25 \pm 0.04$, indicating a trend to yellowness, especially in the samples with higher BPI content regardless of the $\mathrm{pH}$ (G17-A and G17-B). Calculation of WI revealed a significantly lower "perceived" whiteness in samples with the highest BPI content regardless of $\mathrm{pH}$ (G17-A and $\mathrm{G} 17-\mathrm{B})$ as in the case of $\mathrm{b}^{*}$. This could be due to the yellowness/creamy colour of that particular BPI. All these values indicated that the gels were very light in colour and thus suitable for making different food analogues in which light colours are desired or in which the colour can be easily modified.

\section{Oscillatory Measurements}

\section{Stress Sweeps}

The limit values of the linear viscoelastic (LVE) range: the stress amplitude $\left(\sigma_{\max }\right)$, and the strain amplitude $\left(\gamma_{\max }\right)$ (Table 2), evidence that BPI gels had considerable structural stability and adequate conformational flexibility [12].

At lower BPI concentration, both $\sigma_{\max }$ and $\gamma_{\max }$ increased significantly $(p<0.05)$ with increasing $\mathrm{pH}$; specifically $\sigma_{\max }$ increased by $33 \%$ and $\gamma_{\max }$ increased by $158 \%$ in G14-B vs
Table 2 Effect of $\mathrm{pH}$ and BPI concentration on the viscoelastic parameters from small amplitude oscillatory shear (SAOS) tests for bean protein isolate (BPI) gels at $20{ }^{\circ} \mathrm{C}$. 2a Viscoelastic parameters for the linear viscoelastic (LVE) range at $1 \mathrm{~Hz}$

\begin{tabular}{llll}
\hline Sample & $\sigma_{\max }(\mathrm{Pa})$ & $\gamma_{\text {máx. }}(\%)$ & $\mathrm{G}^{*}(\mathrm{kPa})$ \\
\hline G14-A & $1500 \pm 150^{\mathrm{a}}$ & $4.23 \pm 0.71^{\mathrm{a}}$ & $39.0 \pm 3.8^{\mathrm{c}}$ \\
G14-B & $1989 \pm 198^{\mathrm{b}}$ & $10.9 \pm 1.1^{\mathrm{c}}$ & $18.3 \pm 1.9^{\mathrm{a}}$ \\
G17-A & $3796 \pm 380^{\mathrm{d}}$ & $6.76 \pm 0.29^{\mathrm{b}}$ & $58.6 \pm 2.6^{\mathrm{d}}$ \\
G17-B & $3000 \pm 300^{\mathrm{c}}$ & $9.32 \pm 0.62^{\mathrm{c}}$ & $32.2 \pm 2.2^{\mathrm{b}}$ \\
\hline
\end{tabular}

Values are given as mean \pm expanded uncertainty limit (EUL). a-d: Different superscript letters for each parameter indicate significant differences $p<0.05$ among samples

G14-A (Table 2). This result indicates that the slight increase in $\mathrm{pH}$ noticeably enhanced the structural stability and more the conformational flexibility. Moreover, there was a significant decrease $(53 \%)$ in gel strength $\left(G^{*}\right)$ between G14-A and G14-B gels (Table 2), indicating a considerable reduction in the overall rigidity of the protein network at $\mathrm{pH}=7$. A possible explanation for these findings is that beyond the isoelectric range - $\mathrm{pH}=4.8$ and 5.5- of bean proteins [25], a fine-stranded structure would be formed and hence the diameter of the protein strands would decrease [26], which in turn would reduce the overall (elastic and viscous) resistance to deformation (low $G^{*}$ ). In the case of $17 \%$ BPI, the analogous $\mathrm{pH}$ increase was reflected in a similar qualitative trend in the viscoelastic parameters $\left(\gamma_{\max }\right.$ and $\left.G^{*}\right)$, although with lower percentages than at $14 \%$ BPI concentration (Table 2). Naturally, at the higher protein concentration a more compact protein matrix was formed which partially screened the structural effect of $\mathrm{pH}$ on the gel-network density. So, a more fine-stranded structure (Gels-B) would favour a more accessible location of the reactive residues observed in the electrophoretic profiles.

At fixed $\mathrm{pH}$, the increase in BPI concentration, naturally increased $G^{*}$ due to the greater network density in both G17-A vs G14-A and G17-B vs G14-B. However, it should be noted that in lot A gels, $\gamma_{\max }$ was significantly lower at the lower BPI concentration (G14-A vs G17-A). This is a peculiar characteristic of globular proteins, since at lower concentrations the protein aggregates contributing to the structure are shorter and more compact [27] than at higher
Table 1 Colour values of the different bean protein gels

\begin{tabular}{lllll}
\hline Samples & $\mathrm{L}^{*}$ & $\mathrm{a}^{*}$ & $\mathrm{~b}^{*}$ & Whiteness Index \\
\hline G14-A & $75.78 \pm 0.47^{\mathrm{c}}$ & $-0.21 \pm 0.33^{\mathrm{b}}$ & $13.92 \pm 0.39^{\mathrm{a}, \mathrm{b}}$ & $34.02 \pm 1.64^{\mathrm{c}}$ \\
G17-A & $74.80 \pm 0.45^{\mathrm{b}}$ & $0.04 \pm 0.03^{\mathrm{b}}$ & $14.80 \pm 0.19^{\mathrm{b}, \mathrm{c}}$ & $30.41 \pm 0.20^{\mathrm{b}}$ \\
G14-B & $73.55 \pm 0.15^{\mathrm{a}}$ & $-0.83 \pm 0.21^{\mathrm{a}}$ & $12.95 \pm 1.03^{\mathrm{a}}$ & $34.69 \pm 2.19^{\mathrm{c}}$ \\
G17-B & $74.09 \pm 0.25^{\mathrm{a}, \mathrm{b}}$ & $-0.01 \pm 0.04^{\mathrm{b}}$ & $15.25 \pm 0.04^{\mathrm{c}}$ & $28.35 \pm 0.28^{\mathrm{a}}$ \\
\hline
\end{tabular}

Values are given as mean \pm standard deviation. a-c: Different superscript letters for each parameter indicate significant differences $(p<0.05)$ among samples in each parameter 
protein concentrations. That is why a less deformable gel network was formed for G14-A vs G17-A (Table 2).

\section{Frequency Sweeps}

Mechanical spectra of the BPI gels with 14 and 17\% BPI concentration indicated that samples were true gels at both concentrations because G'> G' [28] with slight frequency dependence in both G' and G" (Fig. 3). To quantify their frequency dependence both parameters were fitted to the power law (Eqs. (1) and (2)):

$G^{\prime}=G_{0}^{\prime} \cdot \omega^{n^{\prime}}$

$G^{\prime \prime}=G_{0}^{\prime \prime} \cdot \omega^{n^{\prime \prime}}$

where $G_{0}$ ' and $G_{0}$ " are the elastic and viscous moduli at $1 \mathrm{rad} / \mathrm{s}$, and $n$ ' and $n$ " denote the rate of increase in $G$ ' and $G$ ” respectively with increasing the angular frequency $(\omega)$. The loss factor $\tan \delta=\frac{G_{0}^{\prime \prime}}{G_{0}^{\prime}}$ is a measurement of the solid-like character of gels and provides useful information about the energy of interactions in the gel network [29].
At fixed BPI concentration, the increase in $\mathrm{pH}$ reduced both $G_{0}$ ' and $G_{0}$ " parameters irrespective of the concentration (Table 3). Thus, at $\mathrm{pH}=7$, outside the $\mathrm{pI}$ range of bean proteins, the electrostatic charge in the amino acid residues would increase, so the inter-chain repulsive forces augmented and consequently a more hydrated protein network was formed which would explain the observed softening of the solid matrix in gels B vs A at both 14 and 17\% BPI concentrations (Table 3). This fact is consistent with the lower $\mathrm{L}^{*}$ values for lot B vs A, since L* shows the light scattered by protein aggregates in the gel network. Therefore, at higher $\mathrm{pH}$ the BPI gel network had a less compact protein-matrix, reducing the effect of diffuse reflection and consequently a decrease of $\mathrm{L}^{*}[30]$. In addition, $\tan \delta$ values were significantly lower $(p<0.05)$ in gels B vs A (Table 3$)$ indicating that at $\mathrm{pH}=7$ the ideal network-fraction was enhanced irrespective of BPI concentration [31]. This fact is equivalent to a greater lifetime of protein-protein interactions than that for gels at $\mathrm{pH}=6.5$ [30].

At fixed $\mathrm{pH}$, the increase in BPI concentration logically increased both $G_{0}$ ' and $G_{0}$ ”, indicating a denser protein matrix in a more packed network. However, $\tan \delta$ significantly increased $(\mathrm{p}<0.05)$ in G17 vs G14 irrespective of $\mathrm{pH}$ (Table 3). This trend indicates that higher (17\% BPI
Fig. 3 Mechanical spectra of gels at $14 \%$ and $17 \%$ BPI concentration for lots A and B at $20^{\circ} \mathrm{C}$

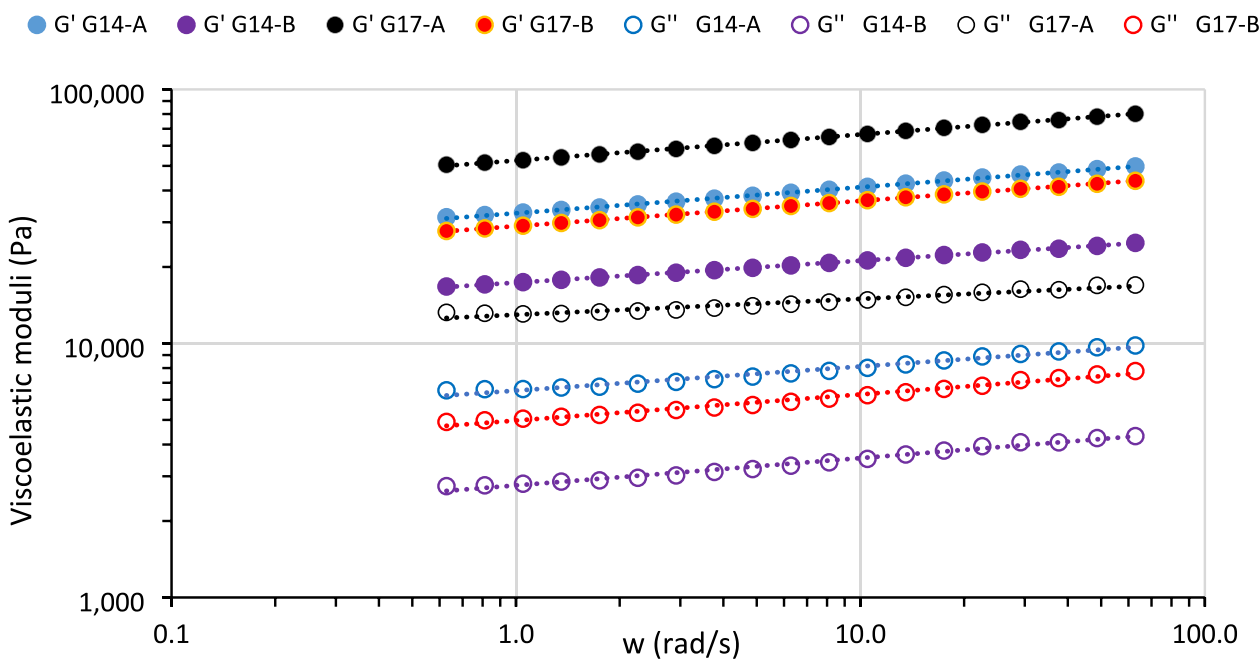

Table 3 Effect of $\mathrm{pH}$ and BPI concentration on the viscoelastic parameters from small amplitude oscillatory shear (SAOS) tests for bean protein isolate (BPI) gels at $20{ }^{\circ} \mathrm{C}$. 2b Fit parameters of mechanical spectra (Eqs. 1 and 2)

\begin{tabular}{|c|c|c|c|c|c|c|c|}
\hline Samples & $\mathrm{G}_{\mathrm{o}}{ }^{\prime}(\mathrm{kPa})$ & n' & $\mathrm{r}^{2}$ & $\mathrm{G}_{\mathrm{o}}{ }^{\prime \prime}(\mathrm{kPa})$ & n" & $\mathrm{r}^{2}$ & $\tan \delta$ \\
\hline G14-A & $32.6 \pm 3.2^{\mathrm{b}}$ & $0.102 \pm 0.001^{b}$ & 0.999 & $6.5 \pm 1.1^{\mathrm{b}}$ & $0.095 \pm 0.004^{\mathrm{c}}$ & 0.977 & $0.199 \pm 0.002^{\mathrm{c}}$ \\
\hline G14-B & $17.35 \pm 0.73^{\mathrm{a}}$ & $0.086 \pm 0.001^{\mathrm{a}}$ & 0.999 & $2.76 \pm 0.53^{\mathrm{a}}$ & $0.107 \pm 0.003^{\mathrm{b}}$ & 0.984 & $0.166 \pm 0.003^{\mathrm{a}}$ \\
\hline G17-A & $52.5 \pm 2.6^{\mathrm{c}}$ & $0.102 \pm 0.001^{\mathrm{b}}$ & 0.999 & $13.0 \pm 3.7^{\mathrm{c}}$ & $0.063 \pm 0.003^{\mathrm{a}}$ & 0.953 & $0.227 \pm 0.006^{\mathrm{d}}$ \\
\hline G17-B & $29.0 \pm 2.1^{\mathrm{b}}$ & $0.100 \pm 0.001^{\mathrm{b}}$ & 0.999 & $4.97 \pm 0.53^{b}$ & $0.103 \pm 0.003^{\mathrm{b}}$ & 0.986 & $0.172 \pm 0.002^{\mathrm{b}}$ \\
\hline
\end{tabular}

Values are given as mean \pm expanded uncertainty limit (EUL). a-d Different letters for each parameter indicate significant differences $p<0.05$ among samples 
concentration, produced a more rigid and less energy-stable inter-protein bonds resulting in a less ideal network-fraction at $17 \%$ vs $14 \%$ BPI [12] more evident in lot A samples. This result is consistent with the greater difference between the two exponents ( $n^{\prime}>n$ ") in G17-A vs G14-A (Table 3), indicating that at the higher BPI concentration, a less time-stable protein matrix was formed, as evidenced by the faster loss of the ideal network fraction (high $n$ ') compared to the nonideal part ( $n$ "). In lot B the same increase in BPI concentration produced similar values for $n^{\prime}(0.100 \pm 0.001)$ and $n$ " $(0.103 \pm 0.003)$ at $17 \%$ BPI concentration (Table 3$)$. These low and comparable exponents ( $n$ ' and $n$ ") corroborate the greater time stability of the protein network [30] produced by the higher BPI concentration at $\mathrm{pH}=7$ (G17-B).

\section{Bioactive Compounds of Selected Bean Protein Isolate Gels}

The content of some bioactive compounds present in different foods is affected by the food matrix and the manufacturing process, increasing or decreasing their content in the end-product. Therefore, it is recommended to determine their presence in novel foods such as vegetable meat or seafood analogue gels.

The studied BPI was analysed in a previous work [2] and it was characterized by the presence of inositol phosphates $(32.67 \mathrm{mg} / \mathrm{g}), \alpha$-galactosides $(14.27 \mathrm{mg} / \mathrm{g})$, lectins $(0.73 \%$ PHA or $0.60 \mathrm{HU} / \mathrm{mg}$ ) and trypsin inhibitors (24.17 TIU/ $\mathrm{mg}$ ). Stachyose and phytic acid, respectively, were the main $\alpha$-galactoside and inositol phosphates found in the isolate. Regarding the PHA content, notably, the BPI contained a very low lectin content since the Almonga variety is a low-lectin seed [5] and thus this BPI can be used safely in the development of new products, especially made at low temperature and/or short time. The higher percentage of BPI produced the larger amount of bioactive compounds in the vegetable gels (Table 4). The content of bioactive compounds in these gels is higher of that reported by Borderias et al. [30] in pea-surimi-like gels containing up to $15 \%$ of pea protein isolate (PPI). This is due to the BPI presented higher amount of bioactive compounds that the commercial PPI studied by these authors. In general, the concentration of these compounds determined in the gels was low; however, the healthy effect of these compounds depends on their intake, and there is not always a threshold level recommended to achieve the healthy effect [2]. Trypsin inhibitors are known to be anticarcinogenic compounds; it has been reported that the traditional Japanese diet contains around 420 protease inhibitor units per day, and a consumption of 25-800 units per day during three month exerts a protective effect against cancer in humans [2] (and citations therein).

According to Martínez-Villaluenga et al. [32] consumption of $3 \mathrm{~g} /$ day of $\alpha$-galactosides produced a clear prebiotic effect,
Table 4 Bioactive compounds content (wet basis) on gels elaborated at two BPI concentrations (14 and 17\%)

\begin{tabular}{lll}
\hline Bioactive compound & G $14 \%$ & G $17 \%$ \\
\hline Inositol phosphates (IP) (mg/g) & & \\
IP3 & $0.06 \pm 0.00^{\mathrm{b}}$ & $0.07 \pm 0.00^{\mathrm{b}}$ \\
IP4 & $0.23 \pm 0.00^{\mathrm{c}}$ & $0.44 \pm 0.03^{\mathrm{b}}$ \\
IP5 & $0.97 \pm 0.03^{\mathrm{c}}$ & $1.96 \pm 0.05^{\mathrm{b}}$ \\
IP6 & $2.55 \pm 0.10^{\mathrm{c}}$ & $6.08 \pm 0.04^{\mathrm{b}}$ \\
Total IP & $3.79 \pm 0.08^{\mathrm{c}}$ & $8.62 \pm 0.12^{\mathrm{b}}$ \\
Trypsin inhibitors (TIU/mg) & $1.42 \pm 0.01^{\mathrm{c}}$ & $2.39 \pm 0.02^{\mathrm{b}}$ \\
Lectins (\%PHA) & $\mathrm{n} . \mathrm{d}$. & $\mathrm{n} . \mathrm{d}$. \\
$\alpha$-galactosides (mg/g) & & \\
Raffinose & $3.01 \pm 0.11^{\mathrm{b}}$ & $4.08 \pm 0.07^{\mathrm{a}}$ \\
Ciceritol & $0.81 \pm 0.07^{\mathrm{b}}$ & $1.01 \pm 0.01^{\mathrm{b}}$ \\
Stachyose & $2.77 \pm 0.14^{\mathrm{c}}$ & $3.90 \pm 0.10^{\mathrm{b}}$ \\
Total galactosides & $5.78 \pm 0.15^{\mathrm{c}}$ & $7.98 \pm 0.13^{\mathrm{b}}$ \\
\hline
\end{tabular}

Values are given as mean \pm standard deviation; $n=4$; n.d. $=$ not detected

increasing the growth of beneficial microbiota, and improving the immune system. Hurrell et al. [33] reported a significant increase in iron absorption when IP6 was below $10 \mathrm{mg} / \mathrm{g}$ protein in one serving of the meal. Most of the surimi manufacturer recommended in the product label consuming one serving/day of around $70-125 \mathrm{~g}$. Thus, taking these gels as vegetable surimilike gels, one serving of $100 \mathrm{~g}$ was chosen to determine the content of the bioactive compounds in one meal. Thus, one serving of these BPI gels supplied from $0.58 \mathrm{~g}(\mathrm{G} 14)$ to $0.80 \mathrm{~g}$ (G17) of total galactosides and one serving of G14 and G17 contained 3.38 and $8.06 \mathrm{mg}$ of IP6 per $\mathrm{g}$ meal protein. In addition, taking into account the presence of these phytochemicals in the vegetable gels, the BPI may be considered an addedvalue ingredient in the development of new foods with specific health roles. One serving of G14 and G17 samples provided 142 and 239 TIUs of trypsin inhibitors, amounts that are in the effective range for prevention or suppression of carcinogeninduced effects [2, 4]. The amount of bioactive compounds supplied by one serving of these BPI gels are higher of that reported that reported by Borderias et al. [30] in pea-surimi-like gels. According to some authors [33, 34] consumption of food with total galactosides content lower than $12 \mathrm{mg} / \mathrm{g}$ and total inositol phosphates $<20 \mathrm{mg} / \mathrm{g}$ (like the studied gels) produced low flatulence and afforded a mineral availability similar to commercial formulas based on soybean protein.

\section{Conclusions}

From the results of the physicochemical, mechanical and viscoelastic properties of the resulting gels it can be concluded that the low-lectin BPI is a legumin-rich isolate with great 
gelation ability at $\mathrm{pH} 7$ (Lot B) in 14 and 17\% BPI concentrations. Rheologically, they rendered less rigid gel networks with improved conformational flexibility, cohesiveness, and time stability than the lot A obtained al $\mathrm{pH}$ 6.5. These findings permit to deduce that Lot $\mathrm{B}(\mathrm{pH} 7$ ) made with 14 and $17 \%$ BPI with $5 \mathrm{U} / \mathrm{g}$ of MTGase was the most suitable for the study objective. Regarding the colour, all the gels showed a slight yellowness/creamy that easily permit gel colour modification. In addition, the light colour of the gels in combination with the viscoelastic and mechanical properties of Lot B, regardless of BPI concentration, would allow the formation of gels with a wide range of textures as the basis of making meat-products and seafood analogues from a vegetal raw material. From a health point of view and according to the literature gels of Lot B contain enough bioactive content to exert a protective effect against some carcinogenic processes, to improve iron absorption, and to produce a prebiotic effect on the microbiota without the discomfort of flatulence.

Supplementary Information The online version contains supplementary material available at https://doi.org/10.1007/s11130-022-00956-5.

Acknowledgements This work was supported by the Spanish Ministry of Economy and Competitiveness (RTA2015-00003-CO2).

Funding Open Access funding provided thanks to the CRUE-CSIC agreement with Springer Nature.

Data Availability Authors declare that datasets are available on request. The raw data supporting the conclusions of this article will be made available by the authors, without undue reservation.

\section{Declarations}

Conflict of Interest The authors declare that they have no conflict of interest.

Open Access This article is licensed under a Creative Commons Attribution 4.0 International License, which permits use, sharing, adaptation, distribution and reproduction in any medium or format, as long as you give appropriate credit to the original author(s) and the source, provide a link to the Creative Commons licence, and indicate if changes were made. The images or other third party material in this article are included in the article's Creative Commons licence, unless indicated otherwise in a credit line to the material. If material is not included in the article's Creative Commons licence and your intended use is not permitted by statutory regulation or exceeds the permitted use, you will need to obtain permission directly from the copyright holder. To view a copy of this licence, visit http://creativecommons.org/licenses/by/4.0/.

\section{References}

1. Shevkani K, Singh N, Chen Y, Kaur A, Yu L (2019) Pulse proteins: secondary structure, functionality and applications. J Food Sci Technol 56:2787-2798. https://doi.org/10.1007/ s13197-019-03723-8
2. Muzquiz M, Varela A, Burbano C, Cuadrado C, Guillamon E, Pedrosa MM (2012) Bioactive compounds in legumes: pronutritive and antinutritive actions. Implications for nutrition and health. Phytochem Rev 11:227-244. https://doi.org/10.1007/ s11101-012-9233-9

3. Carbonaro M (2021) Nutraceutical perspectives of pulses. In: Tiwari BK, Gowen A, McKenna B (eds) Pulse Foods, Academic Press, San Diego, Chapter 17. pp. 423-460. https://doi.org/10. 1016/B978-0-12-818184-3.00017-9

4. Pedrosa MM, Varela A, Domínguez-Timón F, Tovar CA, Moreno HM, Borderías AJ, Díaz MT (2020) Comparison of bioactive compounds content and techno-functional properties of pea and bean flours and their protein isolates. Plant Foods Hum Nutr 75:642-650. https://doi.org/10.1007/s11130-020-00866-4

5. Gupta S, Chhabra GS, Liu C, Bakshi JS, Sathe SK (2018) Functional properties of select dry bean seeds and flours. J Food Sci 83:2052-2061. https://doi.org/10.1111/1750-3841.14213

6. Olmedilla-Alonso B, Pedrosa M, Cuadrado C, Brito M, AsensioS-Manzanera C, Asensio-Vegas C (2013) Composition of two Spanish common dry beans (Phaseolus vulgaris), 'Almonga' and 'Curruquilla', and their postprandial effect in type 2 diabetics. J Sci Food Agric 93:1076-1082. https://doi.org/10.1002/jsfa. 5852

7. Pedrosa MM, Cuadrado C, Burbano C, Muzquiz M, Cabellos B, Olmedilla-Alonso B, Asensio-Vegas C (2015) Effects of industrial canning on the proximate composition, bioactive compounds contents and nutritional profile of two Spanish common dry beans (Phaseolus vulgaris L.). Food Chem 166:68-75. https://doi.org/ 10.1016/j.foodchem.2014.05.158

8. He S, Simpson BK, Sun H, Ngadi MO, Ma Y, Huang T (2018) Phaseolus vulgaris lectins: a systematic review of characteristics and health implications. Crit Rev Food Sci Nutr 58:70-83. https:// doi.org/10.1080/10408398.2015.1096234

9. Kiosseoglou V, Paraskevopoulou A (2011) Functional and physicochemical properties of pulse proteins. In: Tiwari BK, Gowen A, McKenna B (eds) Pulse Foods. Academic Press, San Diego, pp 57-90. https://doi.org/10.1016/B978-0-12-382018-1.00003-4

10. Makri E (2005) Study of functional properites of seed storage proteins from indigenous Europan legume crops (lupin, pea, broad bean) in admixture with poysaccharides. Food Hydrocoll 19:583-594. https://doi.org/10.1013/j.foodhyd.2004.10.028

11. Szczesniak AS (2002) Texture is a sensory property. Food Qual Pref 13:215-225. https://doi.org/10.1016/s0950-3293(01)00039-8

12. Moreno HM, Domínguez-Timón F, Díaz MT, Pedrosa MM, Borderías AJ, Tovar CA (2020) Evaluation of gels made with different commercial pea protein isolate: rheological, structural and functional properties. Food Hydrocoll 99:105375. https://doi.org/10. 1016/j.foodhyd.2019.105375

13. Tang C-H (2008) Thermal denaturation and gelation of vicilinrich protein isolates from three Phaseolus legumes: a comparative study. LWT-Food Sci Technol 41:1380-1388. https://doi.org/10. 1016/j.lwt.2007.08.025

14. Barac M, Pešić M, Stanojevic S, Kostić A, Cabrilo S (2015) Techno-functional properties of pea (Pisum sativum) protein isolates: a review. Acta Per Technol 46:1-18. https://doi.org/10.2298/ APT1546001B

15. Adebiyi AP, Aluko RE (2011) Functional properties of protein fractions obtained from commercial yellow field pea (Pisum sativum L.) seed protein isolate. Food Chem 128:902-908. https:// doi.org/10.1016/j.foodchem.2011.03.116

16. Fernández-Quintela A, Macarulla MT, del Barrio AS, Martínez JA (1997) Composition and functional properties of protein isolates obtained from commercial legumes grown in northern Spain. Plant Foods Hum Nutr 51:331-341. https://doi.org/10.1023/A: 1007936930354 
17. Hayat I, Ahmad A, Masud T, Ahmed A, Bashir S (2013) Nutritional and health perspectives of beans (Phaseolus vulgaris L.): an overview. Crit Rev Food Sci Nutr 54:580-592. https://doi.org/ 10.1080/10408398.2011.596639

18. Akintayo ET, Oshodi AA, Esuoso KO (1999) Effects of $\mathrm{NaCl}$, ionic strength and $\mathrm{pH}$ on the foaming and gelation of pigeon pea (Cajanus cajan) protein concentrates. Food Chem 66:51-56. https://doi.org/10.1016/S0308-8146(98)00155-1

19. Lawal OS (2004) Functionality of African locust bean (Parkia biglobossa) protein isolate: effects of $\mathrm{pH}$, ionic strength and various protein concentrations. Food Chem 86:345-355. https://doi. org/10.1016/j.foodchem.2003.09.036

20. Meng GT, Ma C-Y (2001) Thermal properties of Phaseolus angularis (red bean) globulin. Food Chem 73:453-460. https://doi.org/ 10.1016/S0308-8146(00)00329-0

21. Mühling M, Gilroy J, Croy RRD (1997) Legumin proteins from seeds of Phaseolus vulgaris L. J Plant Physiol 150:489-492. https://doi.org/10.1016/S0176-1617(97)80103-4

22. Liu C, Damodaran S, Heinonen M (2018) Effects of microbial transglutaminase treatment on physiochemical properties and emulsifying functionality of faba bean protein isolate. LWT-Food Sci Technol 99:396-403. https://doi.org/10.1016/j.lwt.2018.10. 003

23. Damodaran S, Agyare KK (2013) Effect of microbial transglutaminase treatment on thermal stability and $\mathrm{pH}$-solubility of heatshocked whey protein isolate. Food Hydrocoll 30:12-18. https:// doi.org/10.1016/j.foodhyd.2012.04.012

24. Djoullah A, Djemaoune Y, Husson F, Saurel R (2015) Native-state pea albumin and globulin behavior upon transglutaminase treatment. Process Biochem 50:1284-1292. https://doi.org/10.1016/j. procbio.2015.04.021

25. Sathe SK (2002) Dry bean protein functionality. Crit Rev Biotechnol 22:175-223. https://doi.org/10.1080/07388550290789487

26. Munialo CD, van der Linden E, de Jongh HHJ (2014) The ability to store energy in pea protein gels is set by network dimensions smaller than 50nm. Food Res Int 64:482-491. https://doi.org/10. 1016/j.foodres.2014.07.038

27. Zhang Y-H, Wen Q-B, Yang X-Q, Li L, Deng W-L (2010) Thermal aggregation and gelation of kidney bean (Phaseolus vulgaris
L.) protein isolate at $\mathrm{pH} 2.0$ : influence of ionic strength. Food Hydrocoll 24:266-274. https://doi.org/10.1016/j.foodhyd.2009. 10.002

28. Cando D, Moreno HM, Tovar CA, Herranz B, Borderías AJ (2014) Effect of high pressure and/or temperature over gelation of isolated hake myofibrils. Food Bioprocess Technol 7:3197-3207. https://doi.org/10.1007/s11947-014-1279-9

29. Herranz B, Borderías AJ, Solas M, Tovar CA (2012) Influence of measurement temperature on the rheological and microstructural properties of glucomannan gels with different thermal histories. Food Res Int 48:885-892. https://doi.org/10.1016/j.foodres.2012. 07.005

30. Borderías AJ, Tovar CA, Domínguez-Timón F, Díaz MT, Pedrosa MM, Moreno HM (2020) Characterization of healthier mixed surimi gels obtained through partial substitution of myofibrillar proteins by pea protein isolates. Food Hydrocoll 107:105976. https://doi.org/10.1016/j.foodhyd.2020.105976

31. Nijenhuis KT (1997) In: Nijenhuis KT(ed) Thermoreversible networks. Viscoelastic properties and structure of gels. Advances in Polymer Science. Springer-Verlag Berlin Heidelberg. https://doi. org/10.1007/BFb0008699

32. Martınez-Villaluenga C, Torres A, Frias J, Vidal-Valverde C (2010) Semolina supplementation with processed lupin and pigeon pea flours improve protein quality of pasta. LWT-Food Sci Technol 43:617-622. https://doi.org/10.1016/j.lwt.2009.11. 001

33. Hurrell RF, Juillerat MA, Reddy MB, Lynch SR, Dassenko SA, Cook JD (1992) Soy protein, phytate, and iron absorption in humans. Am J Clin Nutr 56:573-578. https://doi.org/10.1093/ ajen/56.3.573

34. Fredrikson M, Alminger ML, Carlsson N-G, Sandberg A-S (2001) Phytate content and phytate degradation by endogenous phytase in pea (Pisum sativum). J Sci Food Agric 81:1139-1144. https:// doi.org/10.1002/jsfa.918

Publisher's Note Springer Nature remains neutral with regard to jurisdictional claims in published maps and institutional affiliations. 